DOI: $\underline{\text { http://dx.doi.org/10.17793/rdd.v5i8.866 }}$

\title{
2. ANTÍGONA: ENTRE O DIREITO NATURAL E O DIREITO POSITIVADO
}

\section{ANTIGONE: BETWEEN NATURAL AND POSITIVE LAW}

\author{
Leonardo Marques Kussler ${ }^{1}$ \\ Emerson de Lima Pinto ${ }^{2}$
}

\begin{abstract}
Resumo: As tragédias gregas sempre nos tocam, pois tratam de sentimentos, reações e situações simbólicas que não perdem sentido na contemporaneidade, pois representam o âmago do ser humano. Por isso, cada nova interpretação traz novos elementos que enriquecem discussões que ciclicamente voltam à discussão sociopolítica, jamais caindo em desuso. Neste artigo, propomos uma interpretação da Antígona, de Sófocles, destacando o papel da personagem em relação ao Direito Natural e o Direito Positivado, explorando os limites da expressão da vontade individual da personagem homônima na lei divina e a necessidade do Estado, na figura de Creonte, em adequar tal demanda à lei dos homens. Para tanto, na primeira seção, explicitaremos a história de Antígona, ressaltando os principais aspectos da trama com relação à problemática do Direito, e, na segunda seção, mostraremos que há forte relação na discussão atual do jusnaturalismo e o juspositivismo, com foco na legislação brasileira.
\end{abstract}

Palavras-chave: Antígona. Direito Natural. Direito Positivo. Limites do Direito.

\begin{abstract}
Greek tragedies always move us, because they deal with feelings, reactions and sumbolic situations that do not lose their meaning in contemporaneity, since they represent the core of human being. Therefore, each new interpretation bring new elements, which enrich discussions that cyclically return to socio-political discussion, and never falling in disuse. In this paper, we propose an interpretation of Sofocle's Antigone, highlighting character's role related to Natural Law and Positive Law, exploring the limits of individual expression of will of the homonymous character in divine law and the necessity of the State, in the figure of Creon, to adequate such demand to the law of men. To do so, in the first section, we will turn
\end{abstract}

1 em Filosofia pela Universidade do Vale do Rio dos Sinos, Bolsista Prosup/Capes. E-mail: leonardo.kussler@gmail.com.

${ }^{2}$ Doutorando em Filosofia pela Universidade do Vale do Rio dos Sinos - UNISINOS. Advogado. Mestre em Direito Público UNISINOS. Especialista em Ciências Penais PUCRS. Professor no Curso de Graduação e Direito no CESUCA e UNISINOS. Pesquisador do CESUCA. E-mail: ersonlp@terra.com.br. 
explicit the Antigone's history, highlighting the main features of the plot in relation to the problematic of Law, and, in the second section, we will show that there is a strong relation in contemporary discussion on jusnaturalism and juspositivism, focusing on Brazilian legislation.

Keywords: Antigone. Natural Law. Positive Law. Law limits.

Sumário: Introdução 2. Antígona e suas interfaces, 3. As limitações do direito positivado e da lei natural: atualidade da Antígona, Considerações finais, Referências bibliográficas

\section{INTRODUÇÃO}

A atualidade das tragédias gregas é reafirmada toda vez que as revisitamos, seja pelo fato de sempre nos dizerem muito ou pela característica de tratar de questões do íntimo do ser humano, que, justamente por isso, as tornam atemporais. Da famosa tríade tragediógrafa, Sófocles figura como o segundo momento da expressão performática das tragédias gregas, com produção pós-esquiliana e pré-euripidiana. De acordo com Nietzsche (1999), Sófocles já representa uma reviravolta em seu discurso poético, pois considera que seus diálogos e suas personagens são construídos com uma maior base em um espírito apolíneo do que dionisíaco, aos moldes da nova lógica filosófica trazida pela dialética-dialógica socrática.

Antígona trata de uma personagem feminina homônima, que, diferentemente dos papéis normalmente concedidos às mulheres, não é representada como alguém que adquire importância por seus poderes de sedução, mas por sua capacidade de argumentar e de se colocar diante dos editos reais de Creonte, o tirano de Tebas que assume o poder após o falecimento do pai de Antígona, Édipo. Ir contra a lei e contra o poder, personificado pelo tirano tebano, não parece ser tarefa de uma mulher ateniense de sua época, mas Antígona é uma personagem única, que evoca os deuses e as leis divinas em detrimento das leis dos homens, na tentativa de resolver uma problemática pessoal, mas de implicação sociopolítica.

Neste artigo, repensaremos o papel de Antígona como insurgente, isto é, como alguém que se coloca contra o poder e as leis do Estado, readequando o alcance das leis divinas e sua aplicação frente às leis dos homens da polis. Desse modo, compararemos, de modo análogo, a aplicação do direito positivado moderno e sua efetivação na atualidade, de modo que seu limite seja averiguado do ponto de vista jurídico e social com foco na legislação brasileira e 
na representatividade desta. Para tanto, dividiremos o estudo em duas seções principais: a) Antígona e suas interfaces; e b) As limitações do direito positivado e da lei natural: atualidade da Antígona.

\section{ANTÍGONA E SUAS INTERFACES}

A tragédia sofocliana Antígona tem um núcleo histórico e um desenvolvimento de trama relativamente simples, mas o que mais nos põe a pensar não são esses aspectos, mas suas implicações na realidade e no que podemos compreender a partir deles, isto é, como podem fazer sentido em nossa realidade, em nosso modo de ser. É sua tentativa de resolver seus problemas com as próprias mãos, sob as penas da lei, que traduz sua atualidade e mostra os limites do Estado em relação à manutenção social e à ética. A possibilidade de o discurso particular de Antígona fazer sentido na esfera pública também nos faz pensar na representatividade do privado no público, além da figura do Estado, que se faz presente na figura de Creonte, que atua nas funções legislativa, executiva e judiciária de uma só vez.

Para fins didáticos, retomemos a história, em linhas gerais. Dois irmãos de Antígona (Etéocles e Polinice) lutaram em exércitos diferentes, Etéocles pelo exército tebano e Polinice pelo exército inimigo. Ambos tomaram em batalha, mas por ser considerado inimigo e traidor de Tebas, Polinice não poderia ser sepultado nem ter honrarias fúnebres, de acordo com o edito real do tirano tebano, Creonte. Antígona relata à sua irmã, Ismênia, que acha injusto o edito real e que é indigno deixar o irmão insepulto, à mercê das aves de rapina. Ismênia não toma parte da ação, por medo, mas Antígona tenta realizar o sepultamento do irmão, acreditando que a lei divina, que prevê o trabalho fúnebre a todo ser humano, estaria acima da lei do homem. Por fim, Antígona é descoberta, e Creonte manda sepultá-la viva em um jazigo, sem saber que seu filho, Hémon - que é noivo de Antígona - , trancafiara-se com Antígona e, ao vê-la enforcada, suicida-se, o que leva ao descontentamento e suicídio de sua mãe e esposa de Creonte, Eurídice. E o grande momento catártico de sofrimento e libertação final faz Creonte pensar nos limites de suas leis e na possível limitação em relação ao divino.

Na verdade, a aliança do irmão Polinice com o exército de Argos era pela linhagem real de seu pai, Édipo, negada por Creonte. De certa forma, o ato de Antígona é uma afronta por não reconhecer a soberania de Creonte. Em uma interpretação hegeliana, “[...] Antígona figura o limite entre a relação e o estado, uma transição na Fenomenologia que não é 


\section{Revista Diálogos do Direito \\ http://ojs.cesuca.edu.br/index.php/dialogosdodireito/index}

ISSN 2316-2112

precisamente uma Aufhebung, pois Antígona é ultrapassada sem ao menos ser preservada quando emerge a ordem ética" (BUTLER, 2000, p. 5). Na perspectiva hegeliana, Antígona é representada como uma figura pré-política, que, ao fim, é suprimida pela lei positivada, pelo Estado. $^{3}$

O crime - dependendo de como se reconhece o ato da personagem - chega a Creonte através do discurso, da linguagem. ${ }^{4}$ Primeiro, Creonte fica sabendo por intermédio de um relato de um mensageiro, que alguém jogara terra sobre o corpo do insepulto; depois, o mensageiro afirma que os guardas viram e prenderam a responsável pela ação, trazendo-a à corte. Antígona afirma ser autora do ato, confessando: "Declaro e não nego meu ato" [xaì

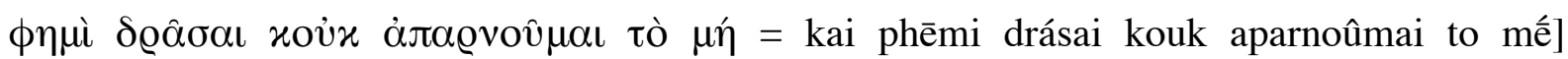
(SÓFOCLES, 1912, Ant., 443). É curioso como a autoridade do tirano seja delegada, de certo modo, pois Creonte não exerce diretamente seu poder, mas manda seus vassalos cuidarem da infratora, prendê-la e trazê-la ao palácio. A força e o reconhecimento da lei está no discurso de Creonte, que tem voz de prisão, voz de condenação, isto é, a linguagem do poder.

O núcleo da obra apresenta um conflito entre as normas da casa (oĩxo 5 = oîkos) e do Estado $(\pi$ ó $\iota \varsigma$ = pólis), do privado em relação ao público, da organização ética de uma família à ordenação social de um Estado constituído. Como afirmam Oudemans e Lardinois (1987, p. 110), “Na concepção hegeliana, Creonte e Antígona são ambos representantes de potências éticas (sittliche Machte) de igual força e justiça. A lei pública do Estado, o amor e o dever à família são opostos como uma luta de aspectos unilaterais de justiça”. São unilaterais, pois ambos esquecem-se que pertencem ao outro lado - o tirano, que é futuro sogro de Antígona, e esta, que, por sua vez, é futura nora de Creonte. Ambos são guiados pela vontade em detrimento do caminho mais razoável e prudente - e, na verdade, isso é uma das poucas

3 Judith Butler é reconhecida mundialmente por suas pesquisas que alternam da filosofia à psicologia no que se refere às questões de gênero e feminismo. $\mathrm{O}$ foco de sua pesquisa sobre a Antígona, na verdade, é mostrar como a personagem usa de artifícios retóricos, instituindo-se como capaz de voz autoritativa em sua insubordinação ao edito de Creonte. Ora, usar a voz na dimensão pública da política é tarefa masculina, na Antiguidade, o que leva a pensar que Antígona tira o poder da masculinidade conferido ao tirano quando se recusa a ouvir à lei humana em benefício à lei divina e faz uso do discurso, da retórica, contra o tirano

4 A propósito da linguagem, vale ressaltar que os nomes das personagens têm função representativa de suas personalidades ou daquilo que representam na história. Polinice, por exemplo, significa muitas

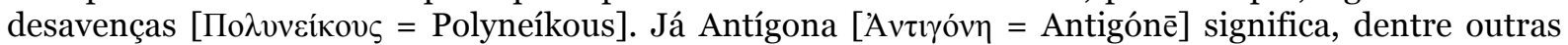
coisas, ir contra, isto é, alguém que se posiciona contra outrem, que quer resolver o elemento agônico

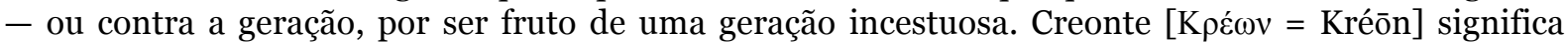

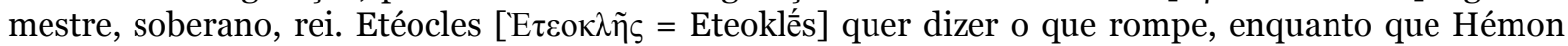
[Aïr $\omega v=$ Haímōn] representa tanto alguém que é talentoso, mas também faz referência ao sangue

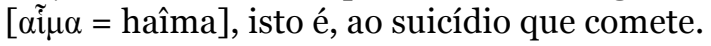


coisas que unifica os discursos dissonantes e ambíguos de Creonte e Antígona. Ismênia, irmã de Antígona, tenta dissuadi-la desde o início, afirmando ser loucura contrapor-se ao poder e a quem está no poder, pois a função feminina, na Antiguidade, estava reduzida ao respeito e à servidão aos homens, e não à postura desregrada que a irmã enxerga em Antígona. Eis que

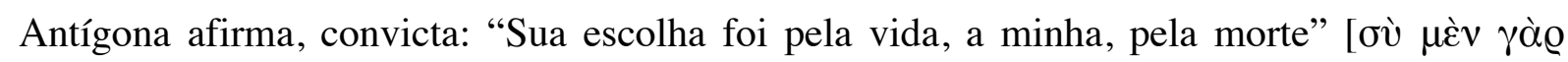

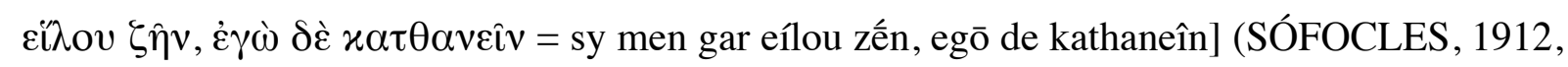
Ant. 555)

Enquanto Antígona permanece resoluta na efetivação de sua vontade de contrariar a lei escrita em benefício da lei não escrita, Creonte defende que - em uma postura, que, contemporaneamente, chamaríamos de contratualista - devemos colocar-nos à disposição da lei geral em detrimento dos acordos interpessoais: "E se qualquer homem acha que um amigo

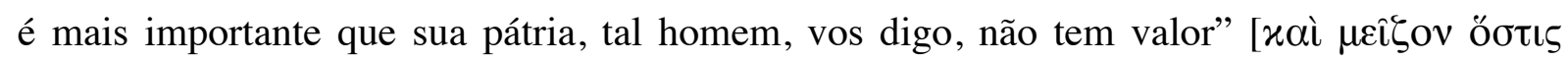

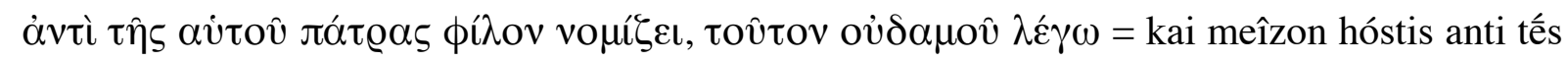
autoû pátras phílon nomízei, taûton oudamoû légō] (SÓFOCLES, 1912, Ant. 182-183). Além disso, o coro o enaltece: "E o poder é seu, acredito, para fazer uso de qualquer lei que seja,

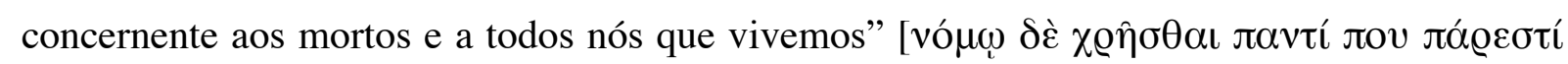

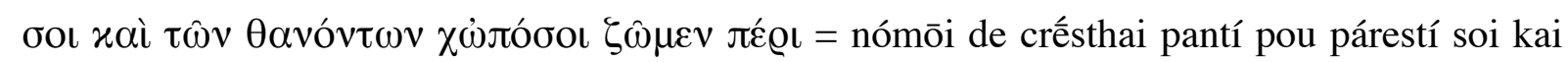
tốn thanóntōn chōpósoi zốmen péri] (SÓFOCLES, 1912, Ant. 213-214). É o típico tema da representação do direito sobre o poder, compreendendo-se que, ao fim, o que resta a Creonte é o reconhecimento, através do coro, que a justiça não deveria transpassar a divindade, agindo de forma ímpia para com os deuses, de modo que "A vitória piedosa de Antígona é especialmente memorável, uma vez que sua família é espetacularmente ímpia, culpada dos crimes mais abomináveis contra a família” (AHRENSDORF, 2009, p. 86).

Até hoje, lemos em textos oficiais publique-se e cumpra-se, de modo que a lei escrita não foi efetivada para questionamentos, mas para ser cumprida. Em Antígona, o caso é exatamente o mesmo, pois a expectativa de Creonte era de tornar público seu edito real e, através da publicidade, estender sua voz autoritativa aos membros de Tebas. A personagem Antígona representa uma desobediente civil, como no clássico de Henry D. Thoureau, pois busca subverter a ordem social, por não acreditar que a lei advinda dos próprios deuses seja inferior - até por uma questão lógica, do universal que não se reduz ao particular — à lei dos homens. O edito era contra sepultar, mas não havia regulação de nada a respeito de cobri-lo 
de terra para não atrair animais de rapina.

Desse modo, os fatos constituem-se por ter caráter jurídico, e dos fatos nascem as relações jurídicas constituídas a partir de uma compreensão dogmática estatal que formam a norma que melhor interpreta aqueles atos dispostos e as maneiras de se agir em sociedade em determinadas situações. Nesse sentido, tais normas regulam a conduta humana (como o crime de Antígona), importando ao ser o seu agir como um ato lícito ou ilícito. Nesse contexto, entende-se que a conduta humana é a precursora da ciência jurídica (REALE JUNIOR, 1998, p. 16-17), portanto, é na situação que se procura obter as normas jurídicas reguladoras, ou seja, é nela que se procura compreender o direito e como ele se concretiza no espaço e no tempo. Então, é necessário aprender e interpretar o agir humano através de propostas jurídicas que interpretem as condições, os destinatários e as necessidades humanas a fim de corrigir e regular através de normas jurídicas que sirvam como mandamentos, permissões e atribuições de todos os gêneros em determinada sociedade. Portanto, o Direito positivo (como o disposto no edito real de Creonte) descreve a forma como deve ser concretizada a norma jurídica enunciada em razão a determinadas ações humanas, e, assim, a consequência jurídica é o resultado previsto pela norma jurídica para o ato ou fato descrito em sua hipótese, conforme Hans Kelsen (1999, p. 50-54).

Parte da punição de Creonte é constituída pelo fato de Antígona não poder sair impune, pois isso seria uma covardia afeminada: "Na verdade, não sou homem, mas ela o é,

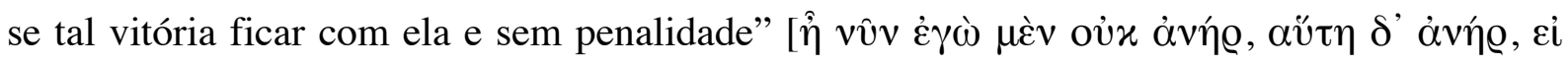

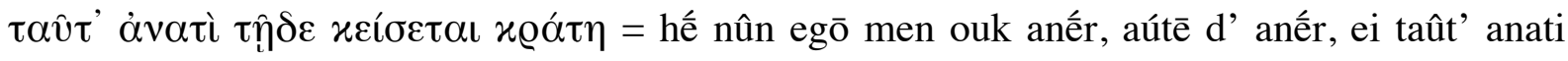
tếide keísetai krátē] (SÓFOCLES, 1912, Ant. 484-485). Na visão de Creonte, representante da voz masculina do poder, seu edito deveria ser facilmente cumprido, pois a ordem não foi posta para ser questionada, especialmente por uma mulher. $\mathrm{O}$ tirano entende que se submeter publicamente às demandas de Antígona seria mostrar fraqueza, deixar-se dominar por uma

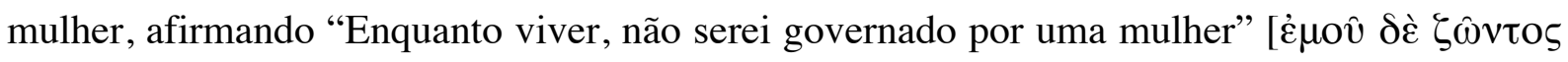

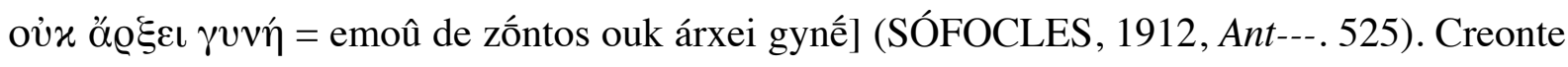
é, nas palavras de Winnington-Ingram (1980, p. 126-127), “[...] um 'realista', para quem apenas o visível é real. O conjunto de motivos que ele é capaz de compreender é limitado, incluindo desejo por poder e ganância por dinheiro. $\mathrm{O}$ fato da morte ele deve aceitar, mas $\mathrm{o}$ reino invisível do morto não significa nada para ele" - pensemos nos dois casos de suborno 
que ele credita aos guardas, por não terem visto o criminoso na primeira tentativa de enterro de Polinice, e a Tirésias, a quem ele acusa de estar buscando profetizar em troca de dinheiro.

Creonte não admite que os deuses possam se interessar pela morte de Polinice. Pelo fato de ele não se importar, como legislador; logo, o divino também não o pode. A preocupação do tirano se transfere para a corrupção dos guardas que poderiam ter sido subornados para não ver o que estava ocorrendo diante de seus olhos. O guarda - que faz vezes de mensageiro - faz brincadeiras: 1) demora para dar a má notícia, pois más notícias não são bem-vindas; 2) pergunta se sua mensagem faz mal aos ouvidos ou à alma de Creonte; 3) chama Creonte de presunçoso, visto que este afirma que o guarda fora subornado. É este mesmo guarda que se redime, aos olhos do tirano, ao trazer Antígona ao palácio. É interessante notar como a utilidade do guarda só se efetiva quando ele faz o que o soberano deseja, visto que o próprio Creonte não age para efetivar sua normatização.

Em Kelsen (1999, p. 200-203), o Estado é compreendido dentro de uma lógica positivista-normativista numa organização política, conceituado por sua forma de coação formulada de indivíduo a indivíduo, de modo a formar a ordem jurídica - como no caso de Creonte em relação à delegação de funções e à ordem jurídica. Um Estado só é compreendido como tal quando formula uma organização a fim de obter uma ordem jurídica que se efetiva a partir da divisão estatal, das delegações de funções.

Na presença de Creonte, Antígona reclama da lentidão do legislador tirano - talvez, isso faça-nos pensar na morosidade de nosso sistema legal, em especial o brasileiro. A díade lei divina e lei humana acompanha a história inteira, e, do ponto de vista de Antígona, sua obediência aos deuses - que representa sua resolução privada, mas baseada em um princípio cosmológico universal, da esfera do divino - é instituída em uma lei de Zeus, que é não escrita, tampouco pode ser revogada. Para Antígona, seu ato não fora de vergonha, tal como quer Creonte, pois o rito fúnebre ao deus Hades se aplica a todo mortal, independentemente de sua ação em vida - o que vai contra à sentença do coro, que coloca Creonte na posição de legislador dos vivos e dos mortos, além do direito divino - , enquanto Creonte defende, de modo maniqueísta, que os irmãos são pré-julgados, em vida, por suas ações contra à terra natal. Seu argumento é de que “[...] o kakos não deve receber honras igualmente ao chrestos, e um inimigo nunca é um amigo, mesmo na morte" (BLUNDELL, 1991, p. 119). Desse modo,

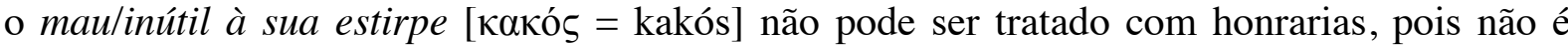




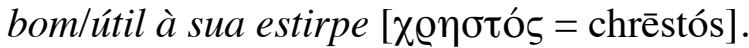

Antígona é uma espécie de meta-humana, pois além da maldição de ser fruto de incesto, também era serva da morte, pois não se realizara em vida. Sua morte foi uma forma de afirmação de sua existência, daquilo que representava. Pensando em Édipo em Colono, Édipo pede para ser enterrado em Tebas, mas tem seu pedido negado devido ao seu crime e acaba por ser sepultado na ilha de Teseu. Portanto, o enterro de Polinice pode ser, simbolicamente, um enterro de se pai. "O enterro assertivo de Antígona, que ela realiza duas vezes, pode ser compreendido como sendo para ambos, um enterro que, de uma só vez, reflete e institui o equívoco do irmão e do pai” (BUTLER, 2000, p. 61).

Também em Édipo em Colono, Édipo afirma que parte da maldição que Antígona herdara do pai era de ele ser o homem de sua vida, visto que é Antígona que passa a acompanhar o pai, quando este perfura os olhos e é exilado de Tebas (SÓFOCLES, 1912). Antígona perde sua juventude ao acompanhar o pai em suas andanças, até sua morte. Hémon, filho de Creonte, era noivo de Antígona, mas submisso ao pai até a decisão paterna contra sua amada. Desse modo, os filhos servem como forma de manutenção do status quo, sem questionar os pais. Na visão de Creonte, "Aquele que a cidade nomeou deve ser obedecido em

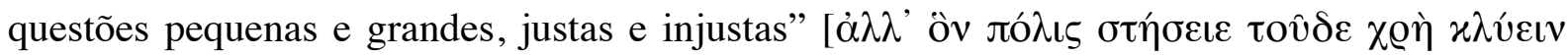

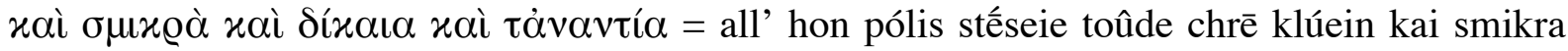
kai díkaia kai tanantía] (SÓFOCLES, 1912, Ant. 666-667).

Entretanto, Hémon fala do desgosto popular diante da atitude de Creonte, colocando em dúvida a exclusividade da certeza e da justiça da decisão deste e aconselhando-o prudência da vontade do povo -- uma espécie do que conhecemos pela moral provisória cartesiana. Hémon quer mostrar que o autoritarismo de Creonte é contra à lei divina, portanto,

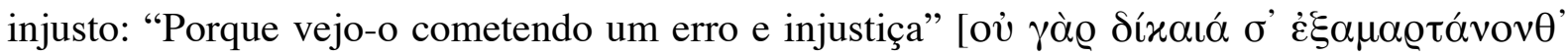
o̊@ô = ou gar díkaiá s’ examartánonth' horố] (SÓFOCLES, 1912, Ant. 743). Enquanto isso, Antígona é condenada a ser encerrada viva em túmulo subterrâneo, pensando ser culpabilizada também pelos crimes não prescritos de seu pai. Segue ao túmulo ainda virgem - o que representa fortemente a não realização da vida, que se resumiria, em parte, pela geração de filhos - , noiva e não casada, por querer honrar o irmão que não mais poderia ter - pois perdera pai e mãe.

A figura do aconselhamento divino e divinatório é representada por Tirésias, o 
adivinho profético cego - reconhecido pela clarividência, as profecias em Tebas e o contato oracular do deus Apolo já na história de Édipo Rei - , que apela para que Creonte não profane um cadáver, de quem quer que seja, pois sua teimosia o levaria à imprudência - de certo modo, falando com mais propriedade aquilo que Hémon havia questionado. Algum descendente de Creonte pagaria com vida por sua decisão. Tirésias afirma que é importante raciocinar prudentemente, informando que Creonte não o está fazendo, pois não se encontra em seu melhor juízo emitindo tal edito a agindo de tal forma. O que Tirésias recebe em troca é o descrédito e a acusação de buscar amedrontar Creonte com suas palavras em troca de dinheiro. Quem acha que sabe de tudo, não tem ouvidos para o outro, não está aberto ao diálogo, pois seu saber torna-se forma de imposição de autoridade. Quando Creonte decide dar ouvidos ao que Tirésias e Hémon haviam falado, já não há mais o que fazer: seu filho suicidara-se e, posteriormente, sua esposa, Eurídice, também. Contraditoriamente, o homem que defendera a lei do Estado acima da lei da família fica transtornado ao perder filho e mulher, pois sua existência estava mais ligada à família do que o personagem transparecia.

Na próxima seção, adentraremos à problemática jurídica especificamente, mostrando a atualidade e a relevância da temática abordada na Antígona, de modo que seja possível perceber como sua discussão é extemporânea e os problemas da época de Sófocles encontram-se parcialmente ou não resolvidos até hoje.

\section{AS LIMITAÇÕES DO DIREITO POSITIVADO E DA LEI NATURAL: ATUALIDADE DA ANTÍGONA}

Uma das principais problemáticas contemporâneas abordadas na Antígona é o conflito entre as normas privadas e a submissão à lei institucional. Aliás, a sobreposição das normas do núcleo familiar em relação à normatização civil se faz presente até hoje. No período absolutista moderno, a sobreposição da vontade popular em detrimento da vontade singular de um soberano já é prevista nas primeiras teses contratualistas - isto é, a vontade particular de um soberano imperava sobre a vontade particular de cada membro da sociedade e da vontade da maioria representada pela expressão popular.

Entretanto, pensando em nossa realidade brasileira contemporânea, de uma democracia jovem e frágil, vemos a representação da vontade da maioria em sua instituição democrática, de modo que a lei instituída, positivada, torna-se parâmetro para todos, a partir 
da vontade da maioria. Obviamente, não vemos toda essa representação na prática, pois assim como há leis que são criadas com base em plebiscitos e referendos, que preveem participação popular direta, após a constituinte, há aquelas que são criadas pelos deputados e senadores já eleitos, que representariam, indiretamente, a vontade e o interesse da população.

A democracia, por conseguinte, pressupõe a ideia de autodeterminação e de conformidade com a ordem jurídica e a vontade da maioria, e o Estado, segundo Kelsen (2005, p. 446) é compreendido como ordem jurídica. Numa sociedade pluralista, a ordem jurídica deve compor normas de natureza central que sejam válidas para certos territórios. A afirmativa simplificadora da supremacia da Constituição sobre a lei e a determinação da intensidade da vinculação jurídico-constitucional do legislador não são suficientes, se não verificadas com a controvertida conciliabilidade da lógica da Constituição de um Estado de Direito, com a lógica da democracia, ao mesmo tempo realizada sob o escudo do questionamento estrutural-material da densidade e abertura das normas constitucionais até a própria compreensão da Constituição em si mesma.

A visível adequação ou conformação de normas infraconstitucionais preexistentes, a partir dos próprios diplomas legais, e por conceitos que fundam seus institutos em matéria penal e constitucional, impõe a instrumentalização de um Estado Democrático de Direito. Auxilia-nos, nesta tarefa, a incorporação de imediato de conceitos como força dirigente pelo carácter determinante de uma lei fundamental garantidora de Direitos Humanos e Fundamentais. Tal escolha teórica implica, de modo indispensável, uma indagação alargada, tanto no plano teórico-constitucional como no plano teórico-político, sobre a função e estrutura de uma Constituição e, complementarmente, teórico-penal (garantismo), remetendonos à resistência daqueles que se opõem à junção desses elementos (o processo a que foi submetida Antígona, por exemplo). A cultura que por nós será formadora da Constituição, por Bhabha (2003, p. 19), é proporcionada no Espaço Pós-moderno, ${ }^{5}$ o que, segundo o autor, acaba sendo um elemento que dificulta ainda mais a construção de uma concepção que ampare na Constituição uma unidade social real, o que traz dificuldade para a afirmação da Constituição como cultura no processo de [re]afirmação de parâmetros contemporâneos para

5 "É o tropo dos nossos tempos colocar a questão da cultura na esfera do além. Na virada do século, preocupa-nos menos a aniquilação - morte do autor - ou a epifania - o nascimento do 'sujeito'. Nossa existência hoje é marcada por uma tenebrosa sensação de sobrevivência, de viver nas fronteiras do presente, para as quais não parece haver nome próprio além do atual e controvertido deslizamento do prefixo ‘pós'; pós-modernismo pós-colonialismo, pós-feminismo” (BHABHA, 2003, p. 19). 
o constitucionalismo em um mundo multicultural assegurador de valores democráticos (Cf. SEMPRINI, 1999, p. 142-143).

Em nossa atual Constituição, no artigo 17, é tratada de que forma os partidos devem reger seus estatutos. É livre a criação, fusão, incorporação e extinção, desde que assegurados a soberania nacional, o regime democrático, o pluripartidarismo, os direitos fundamentais da pessoa humana, de modo que os partidos políticos devem revestir caráter nacional, não podem receber recursos financeiros nem se subordinar à entidade ou ao governo estrangeiro, devendo prestar contas à Justiça Eleitoral e ter funcionamento parlamentar de acordo com a lei. Os partidos têm autonomia para definir estrutura interna, organização e funcionamento, e seus estatutos contêm normas de fidelidade e disciplina partidárias de maneira a não violarem os preceitos democráticos sobre os quais se assenta a Constituição da República. Os partidos são abertos a todos os cidadãos, sem discriminação, pois estes são, espera-se, democráticos, pelas ideias que apresentam nos discursos que propagam. Na realidade, está ausente no modo de ser dos partidos uma demonstração de estima aos seus filiados, não se podendo sequer referir em prática igualitária de procedimentos partidários, já que a maioria possui um sistema burocratizado de procedimentos participativos com seus filiados. Na prática, em diversas oportunidades, os partidos políticos não passam de aparelhos unicamente existentes para os confrontos eleitorais - deixando a deseja no que se refere à representação política dos cidadãos.

Para orientar os eleitores, existem restrições a respeito do direito de votar: a) o eleitor deve ter a possibilidade de agir livremente no momento de votar. Não pode haver coação, o que vicia a vontade do eleitor, e faz com que não haja autenticidade no pronunciamento do eleitor, o que compromete todo o processo eleitoral, que perde seu caráter democrático; b) o eleitor deve ter consciência do significado do seu ato. Pretende-se que o eleitor tenha razoável noção de organização do Estado e das competências atribuídas aos eleitos, para votar com responsabilidade, mas nem todos os que possuem os requisitos legais têm esse conhecimento. Diante disso, cabe aos governos democráticos promover a educação política do eleitorado, divulgando tais informações nos meios de comunicação, a fim de conceder ao povo ampla possibilidade para exercer seus direitos políticos (DALLARI, 1995, p. 160).

Ao retomar a tragédia de Antígona e seu protagonismo social e político, constata-se que, hoje, no Brasil, há uma tentativa de garantir espaços efetivos de participação política à 
mulher, como política pública de igualdade afirmativa (cotas), com o advento da Lei $\mathrm{n}$. 9.504/1997, que aumentou o percentual mínimo de mulheres candidatas para 30\%. De acordo com o art. 10 da lei:

Art. 10. Cada partido poderá registrar candidatos para a Câmara dos Deputados, Câmara Legislativa, Assembleias Legislativas e Câmaras Municipais até cento e cinquenta por cento do número de lugares a preencher.

$\S 3^{\circ}$ Do número de vagas resultantes das regras previstas neste artigo, cada partido ou coligação deverá reservar o mínimo de trinta por centro e o máximo de setenta por cento para candidaturas de cada sexo (BRASIL, 1997).

Desse modo, a política de cotas tem procurado estimular a presença de mulheres na política, coagindo partidos políticos a disponibilizarem seus nomes ao processo político eleitoral, o que, de certo modo, ainda não elevou a presença feminina na arena eleitoral, pois acabou sendo prejudicada em razão de algumas medidas legais, como a que prevê um número mínimo de vagas para cada sexo, que ampliou significativamente o número de vagas $(150 \%$ do total de cadeiras disputadas) e ainda não estabeleceu nenhuma sanção ao partido político que não preenche a cota mínima de candidatas mulheres, na medida em que o único constrangimento imposto ao partido político que não atende a essas condições (percentual mínimo de $30 \%$ das vagas com mulheres) restringe-se a não ocupação dessas vagas com homens. Trata-se de uma situação em que as mulheres, diferentemente de Antígona, ganham vez e voz nas tribunas, podendo ser melhores representadas por suas iguais, com proposição de políticas de afirmação de seus direitos e luta por desenvolvimento mais igualitário nas esferas sociais, econômicas, educacionais, políticas etc. O que falta - mas já está em discussão no plenário - é um avanço não apenas para a porcentagem nas candidaturas, mas de vagas asseguradas na câmara e no senado, por exemplo, o que traria, de fato, maior efetividade às mulheres, que representam mais da metade dos eleitores brasileiros.

O povo exerce sobre os governantes um controle (direto e indireto) no regime de soberania popular, e tal regime substitui as antigas formas de governo - como a polis ordenada pela tirania de Creonte, por exemplo —, e já que os modernos rejeitam a ideia de uma democracia direta, que era considerada o grande vício das repúblicas antigas, limitando o direito do povo sobre os governantes, a democracia acabou se reduzindo unicamente ao princípio eletivo dos cargos políticos. Portanto, em uma analogia à Antígona, não há uma 
participação direta e um embate direto com o representante do poder - que não mais figura como soberano incontestável e tirano - , mas sempre via algum vereador, deputado ou senador que, supostamente, representa determinadas porções populares que o elegeram através do voto democrático. Esperava-se que, se os governantes seriam eleitos pelo povo para um mandado de duração limitada, a possibilidade do abuso pelos governantes estaria afastada. A soberania está no povo, já que este é o titular do sufrágio universal, de modo que os poderes estão relacionados. O povo sendo soberano exerce sua cidadania e adquire o papel político de dar legitimidade aos seus representantes através do sufrágio.

\section{CONSIDERAÇÕES FINAIS}

A cultura tem sido compreendida de forma estática e consolidada nos movimentos constitucionais mais significativos a partir de uma cultura contratualista clássica, o que hoje se torna insuficiente em uma sociedade em mutação (construção da democracia com base na participação plural de setores marginalizados), que vislumbra os limites originais da separação tripartite de poderes, a transformação da noção de soberania dos estados, a pouca legitimidade dos instrumentos formais de representação (participação política das mulheres), a ausência de condições objetivas de presença de sujeitos coletivos no processo decisório formal (partidos políticos internamente democráticos), a volatilidade do conceito de cultura no mundo multicultural e sua importância como novo centro afirmativo de legitimação de poder político no Estado Democrático de Direito.

Desse modo, Antígona nos lembra da necessidade de repensarmos a estrutura de um Estado legalmente estruturado e a necessidade da garantia e da efetivação limitada tanto das leis positivadas, frutos do contrato social, quanto das leis naturais, que precedem o contrato. Neste artigo, não esgotamos a possibilidade de tratar de Antígona como uma tragédia que incita ao pensamento reflexivo acerca da realidade contemporânea, em suas esferas social, política, filosófica etc., mas esboçamos algumas problemáticas que se fazem presentes no aparato legal do Estado e na contribuição deste na realização e/ou efetivação da vontade singular, para além da regulação e da normatização que visa subsumir o particular do cidadão no universal do Estado.

$\mathrm{Na}$ primeira seção, mostramos como a personagem Antígona se mostra como insurgente ao sistema legal exercido pelo tirano de Tebas, que desconsidera as relações da 
família, os laços desta com seu filho, Hémon, na efetivação de seu edito real. Dessa forma, a expressão do Direito positivo, na tragédia, baseia-se na desestruturação do Direito natural, de modo que a lei divina na qual Antígona acredita é descreditada e relegada em favor à lei escrita, dos homens. Mostramos também como a figura feminina de Antígona estrutura parte do descontentamento do tirano, pois o poder se efetiva, em sua visão, na figura masculina. Também exploramos a esfera da desobediência civil, em que Antígona se mostra como alguém que vai contra à lei escrita em parte, pois aproveita-se das brechas expressas no edito real para realizar seu feito. Antígona representa a voz da rebeldia com causa, a voz do enfrentamento social e da liberdade frente ao descaso e à opressão do Estado - algo que, talvez, reflete um pouco do que vivemos, hoje, em uma era de tantas primaveras árabes no mundo todo.

Já na segunda seção, exploramos como o Direito brasileiro contemporâneo se organiza em relação à organização estatal, bem como a problemática da figura feminina ainda encontra-se fragilizada no que tange à representação sociopolítica desta no ambiente político. Também abordamos o modo como a organização do Estado e sua disposição legal apresentam-se de forma limitada, pois tolhem parte do direito à representatividade sociopolítica - como no caso da representação feminina nas eleições brasileiras - , ao cuidado e à gestão do próprio corpo - em casos de determinações legais que orientam quanto à educação domiciliar, ao aborto, a decisão por um parto normal, por exemplo —, ressaltando o caráter constitucional em detrimento de uma percepção de resolução civilista, por exemplo.

Por fim, destacamos a necessidade de não se esquecer dos clássicos, como Antígona, dentre tantos outros, que nos fazem refletir sobre problemas do íntimo do ser humano, que perpassam as diferentes épocas, os diferentes regimes políticos, sociais e econômicos, e continuam fazendo sentido ainda hoje. O que reconhece um clássico como tal não é seu autor ou o tema em questão, mas a possibilidade de se interpretar, com renovação de sentido, a cada nova leitura desta. Portanto, pensar na Antígona é pensar nos direitos não reconhecidos, nas pessoas não reconhecidas pelo aparato legal, na possibilidade de mudar o cenário e atualizar questões prementes da pessoa humana.

\section{REFERÊNCIAS BIBLIOGRÁFICAS}

AHRENSDORF, Peter J. Greek tragedy and political philosophy: rationalism and religion 
in Sophocles' Theban plays. Cambridge: Cambridge University Press, 2009.

BHABHA, Homi K. O local da cultura. Belo Horizonte: Editora UFMG, 2003. (Coleção Humanitas).

BRASIL. Constituição (1988). Constituição da República Federativa do Brasil de 1988. Disponível em: <http://www.planalto.gov.br/ccivil_03/constituicao/constitui\% C3\%A7ao.htm>. Acesso em: 15 jun. 2015.

BRASIL. Lei $\mathbf{n}^{\mathbf{0}}$ 9.504, de 30 de setembro de 1997. Estabelece normas para as eleições. Disponível em: <www.planalto.gov.br/ccivil_03/leis/19504.htm>. Acesso em: 15 jun. 2015.

BLUNDELL, Mary W. Helping friends and harming enemies: a study in Sophocles and Greek ethics. Cambridge: Cambridge University Press, 1991.

BUTLER, Judith. Antigone's claim: kinship between life \& death. New York: Columbia University Press, 2000.

DALLARI, Dalmo de Abreu. Elementos de teoria geral do estado. 19. ed. São Paulo: Saraiva, 1995

KELSEN, Hans. Teoria Pura do Direito. Tradução João Baptista Machado. 6. ed. São Paulo: Martins Fontes, 1999.

Teoria Geral do Direito e do Estado. 4. ed. São Paulo: Martins Fontes, 2005.

NIETZSCHE, Friedrich. O nascimento da tragédia: ou helenismo e pessimismo. Trad. notas e prefácio de J. Guinsburg. São Paulo: Companhia das Letras, 1999.

OUDEMANS, T.C.W.; LARDINOIS, A.P.M.H. Tragic ambiguity: anthropology, philosophy and Sophocles' Antigone. Leiden: E.J. Brill, 1987. (Brill's studies in intellectual history, v. 4).

REALE JUNIOR, Miguel. Lições preliminares de direito. 24. ed. São Paulo: Saraiva, 1998.

SEMPRINI, Andréa. Multiculturalismo Combinado. Bauru: EDUSC, 1999.

SOPHOCLES. Sophocles Vol 1: Oedipus the king. Oedipus at Colonus. Antigone. With an English translation by F. Storr. London; New York. William Heinemann Ltd.; The Macmillan Company. 1912. (The Loeb classical library, 20).

WINNINGTON-INGRAM, R.P. Sophocles: an interpretation. Cambridge: Cambridge University Press, 1980.

(Artigo submetido em 08 de julho de 2015, aceito em 12 de agosto de 2015) 